\title{
土の剛塑性理論における極限定理と応用 \\ TWO EXTREMUM THEOREMS AND THEIR APPLICATIONS FOR THE PLASTIC RIGID ANALYSIS IN SOIL MECHANICS
}

\author{
山口柏樹* \\ By Hakuju Yamaguchi
}

要 旨 土のような材料が剛塑性体としての仮定の 下に破壊する荷重を論ずるには, Drucker および Prager の崩壞定理が有用であるがこの定理は金属塑性理論で証 明されている上下界定理を定性的に述べたものである。

本論文では，自重および摩擦強度が無視できない土の ような塑性材料における二つの極限定理（上界，下界定 理）を解析的に導き, かつ応力および速度に不連続性が ある場合の適用性を吟味し, また応力解の一意性をも論 ビた。

\section{1.はしがき}

土の塑性力学では厳密解をうることが一般に困難であ る。したがって一つの解が，応力および変位に関するす べての境界条件を満足していなくても, それなりに有用 な価值をもつものが少なくない。たとえば基礎の支持力 に関する塑性解は一つの典型であって, 金属の剛塑性論 で導かれた Prandti のポンチの解を基本とし，土のよう に摩擦強度があり，しかも重力の影響が大きく効くよう な材料の押込み問題を議論するわけであって,これによ って支持力公式が提案され，これは基礎地盤の極限支持 力を推定する上に広く利用されていることは周知のとお りである。

しかしながらこのようにして求めた解が金属に対する 解の本質的な修正であるのか, 形式的延長となっている に過ぎないのか, 換言すると一意性が保証された正解で あるのかは確かめられていない。同時に正解でないとし たとき, どの程度の近似解であるのか, すなわち土の塑 性理論における極限解析の定理が確立した形で与えられ ていないため, 近似解であるとしてもその評価が一般に 困難である現状といってよかろう。

金属材料の剛塑性理論では変形する塑性域内での応力 の唯一性について Hill (1951) が証明を与えているが, 塑性域での速度解の一意性や, 剛性域での応力解, 速度 解については決定的なことがいえない(Hill, 1956)。

また極限定理としては不界定理または最大塑性仕事の 定理が知られている。これは正解における表面力のなす 仕事率が最大なることを保証するものである(Hill， 1948)。本定理は忍力や速度場に不連続があっても成り

\footnotetext{
* 正会員 工博 東京工業大学教授 土木工学科
}

立つものであって, 正解が未知であるとき, えられた一 つの不完全な解が正しい降伏荷重を越えることがない， すなわち正解の下限として位置づけられることを意味す るものである。したがってポンチの問題での不完全解は 安全側の值を与えるものとなる。

つぎに上下界定理として知られているものは崩壊定理 ともいわれ,Drucker, Prager 等 (1951) は Prandtl-Reuß 材料に関し，比例負荷を加える状態で議論し i）つりあ 、条件と境界条件を満足し，かつ物体内で至るところ降 伏条件に達しないことが保証されるような応力解が見い 出されるなら物体は降伏しない， ii）ある適合する速度 場において外力の仕事率が，内部的エネルギーの消散率 に等しいか，これを越えるときは崩壊が生ずる，ことを 述べている。

彼等はこの定理を拡張し，いかなる完全塑性体であっ ても，それがどんなひずみ履歴のある場合でも適用しう ることを示した (Drucker Prager, 1952)。

しかし土のような圧縮性材料での解析的証明は与えて おらず，たとえば Drucker, Prager* (1952) は土質力 学におけるリミット デザインの具体的な問題を取り上 げているが，上界定理は前述の ii）を暗黙の中に仮定し ている点あいまい性が残されているほか適用性も限定さ れている。

本論文ではこのような基本的問題に関して, いわゆる Mohr-Coulomb の降伏条件にしたがう土の降伏荷重に 関する二つの極限定理を確定した解析形式で記述し，か つ解の一意性の問題を論じるものである。

Mohr-Coulomb の降伏条件式が二次元平面ひずみ状 態の破壊法則を表わすとき, 式に含まれる強度定数 (粘 着力, せん断抵抗角）が何を意味し，いかにして測定す べきかは重要な問題であるが, 現在の段階では決定的な 所論はないように思われる。たとえば三軸対称圧縮せん 断では中間主応力の影響は不明であるし，一面せん断で は中間主応力のみか最小, 最大主応力の值も自由に調節 できない。しかしながら近時各方面で試みられつつある 純粋せん断試験の結果と三軸試験のそれとを対比した Bishop などの見解 (Bishop, 1966) によると, 三軸試験 は平面ひずみ状態で破壊する場合のせん断抵抗角を 1 〜 $4^{\circ}$ 程度過小に評価する傾向にあるといわれている。もち 
ろん各供試体の破壊時の間げき比が同一でない整理方式 による有効忘力に関する強度定数 $\left(c^{\prime}, \phi^{\prime}\right)$ よりも, 土の 塑性理論では Hvorslev のパラメーター $\left(c_{r}, \phi_{r}\right)$ を採用 するのが合理的であること潷者がすでに強調したとお りである(山口，1966)。以上のことから二次元ひずみ状 態での Hvorslev の強度定数をいかに推定すべきかは今 後の問題として残るとしても, 本論文で考える強度定数 はこの意味のものであることは強調したい。

\section{2. 準備 事項}

弾性係数 $E, G$ が無限大である剛塑性材料が変形可能 となり初めるときの荷重を降伏点荷重という。本論文で は間げき圧は考えないとする。

二次元応力平衡方程式を満たし, 境界 $S$ 上の一部 $S_{F}$ で与えられた表面力と一致する応力解で, 物体内では降 伏条件にしたがう塑性状態か, 降伏条件を越えない剛性 域または静止域であるようなものを可容応力と呼ぶ。す なわち直応力は引張りを正とするとき（図一1）に対して

$$
\left.\begin{array}{l}
\frac{\partial \sigma_{x}}{\partial x}+\frac{\partial \tau_{x y}}{\partial y}=0 \\
\frac{\partial \sigma_{y}}{\partial y}+\frac{\partial \tau_{x y}}{\partial x}=r
\end{array}\right\}
$$

$S_{F}$ 上: $: \sigma_{x} l+\tau_{x y} m=F_{x}, \sigma_{y} m+\tau_{x y} l=F_{y} \cdots(2)$

$\Delta$ 内 $: f=\frac{1}{4}\left(\sigma_{x}-\sigma_{y}\right)^{2}+\tau_{x y}{ }^{2}$

$$
-\left(c_{r} \cos \phi_{r}-\frac{\sigma_{x}+\sigma_{y}}{2} \sin \phi_{r}\right)^{2} \leqslant 0
$$

を満足する応力が可容応力である。

図-1

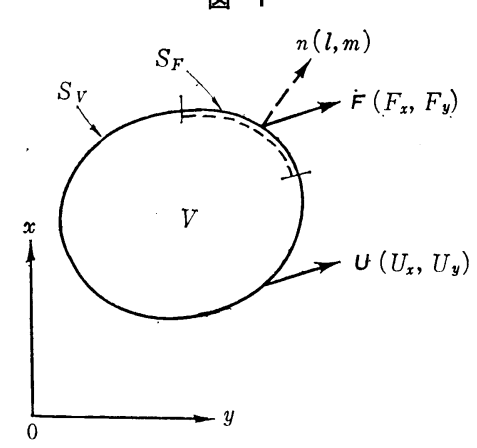

つぎに変形域の要素の速度 $v\left(u_{x}, u_{y}\right)$ から導かれるひ ずみ速度テンソルが等方性条件と圧縮性条件を表わす二 つの基本式を満足し，かつ図一1 の残りの境界 $S_{V}$ 上で 与えられた速度 $\boldsymbol{U}\left(U_{x}, U_{y}\right)$ と一致するとき $\boldsymbol{v}$ を可容速 度と称される。このことを解析的に表わそう。

まず,

$$
\dot{\varepsilon}_{x}=\frac{\partial u_{x}}{\partial x}, \quad \dot{\varepsilon}_{y}=\frac{\partial u_{y}}{\partial y}, 2 t_{x y}=\frac{\partial u_{x}}{\partial y}+\frac{\partial u_{y}}{\partial x}
$$

Mises の塑性ポテンシャルと降伏関数 $f$ が一致する との仮定によると,

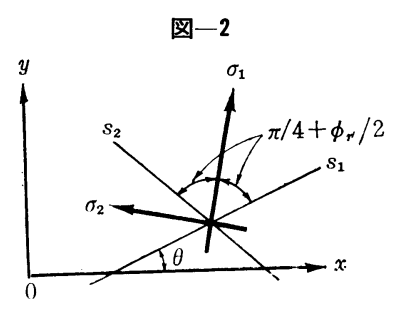

図一 3 Mohr の有効応力円

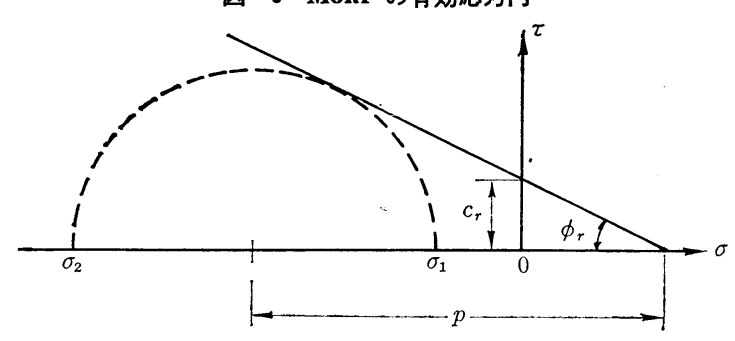

$$
\dot{\varepsilon}_{x}=\lambda \frac{\partial f}{\partial \sigma_{x}}, \quad \dot{\varepsilon}_{y}=\lambda \frac{\partial f}{\partial \sigma_{y}}, \quad \tau_{x y}=\lambda \frac{\partial f}{\partial \tau_{x y}}
$$

ここで式 (3) の $f$ を $\tau_{x y}$ で微分するとき $\tau_{x y}{ }^{2}=\tau_{x y}{ }^{2} / 2$ $+\tau_{y x}{ }^{2} / 2$ と考えて $\tau_{y x}$ を一定と考えて演算する。また は式 (3) が等号のときは正, 不等号のときは 0 となるよ うなスカラー関数である。

さて大きい $\sigma_{1}$ と $\pm\left(\pi / 4+\phi_{r} / 2\right)$ をなす二方向を $S_{1}$, $S_{2}$ すべり方向と呼び， $S_{1}$ すべり線が $x$ 軸となす角を $\theta$ とすると

$$
\begin{aligned}
& \sigma_{x}=-p\left\{1+\sin \phi_{r} \sin \left(2 \theta+\phi_{r}\right)\right\}+c_{r} \cot \phi_{r} \\
& \sigma_{y}=-p\left\{1-\sin \phi_{r} \sin \left(2 \theta+\phi_{r}\right)\right\}+c_{r} \cot \phi_{r} \\
& \tau_{x y}=p \sin \phi_{r} \cos \left(2 \theta+\phi_{r}\right) \\
& p=\frac{\sigma_{1}-\sigma_{2}}{2 \sin \phi_{r}}(>0)
\end{aligned}
$$

ただし，

である。この式と（3）を式（5）に用いると，

$$
\left.\begin{array}{l}
\dot{\varepsilon}_{x}=\lambda p \sin \phi_{r}\left\{\sin \phi_{r}-\sin \left(2 \theta+\phi_{r}\right)\right\} \\
\dot{\varepsilon}_{y}=\lambda p \sin \phi_{r}\left\{\sin \phi_{r}+\sin \left(2 \theta+\phi_{r}\right)\right\} \\
\dot{r}_{x y}=\lambda p \sin \phi_{r} \cos \left(2 \theta+\phi_{r}\right)
\end{array}\right\}
$$

となるが，これは Shield の導いた式と係数 $p \sin \phi_{r}$ を 除けば本質的には変わらず，入の中に含ませて考えれば 同じものである (Shield, 1954)。

等方性の下では応力とひずみ速度の主軸が一致するべ きだが，これは式 (6),(7) から

$$
\frac{\dot{\varepsilon}_{x}-\dot{\varepsilon}_{y}}{2 f_{x y}}=\frac{\sigma_{x}-\sigma_{y}}{2 \tau_{x y}}=-\tan \left(2 \theta+\phi_{r}\right)
$$

のように確かめられる。

$$
\begin{aligned}
& \text { さらに式 (7) の上二式加ら } \\
& \begin{aligned}
\dot{\varepsilon}_{x}\left\{\sin \phi_{r}\right. & \left.+\sin \left(2 \theta+\phi_{r}\right)\right\} \\
& =\dot{\varepsilon}_{y}\left\{\sin \phi_{r}-\sin \left(2 \theta+\phi_{r}\right)\right\}
\end{aligned}
\end{aligned}
$$

なる圧縮性の式がえられる。式 (9) で $\phi_{r}=0$ なら $\dot{\varepsilon}_{x}+$ $\dot{\varepsilon}_{y}=0$ であるから非圧縮条件を表わす。また式 (9)で $\theta=$ 一 $\pi / 4-\phi_{r} / 2$ とおくと, 図一-2より明らかなように $\dot{\varepsilon}_{x} \equiv$ 
$\dot{\varepsilon}_{1}, \dot{\varepsilon}_{y} \equiv \dot{\varepsilon}_{2}$ であるので

$\dot{\varepsilon}_{1}+\dot{\varepsilon}_{2}=\left(\dot{\varepsilon}_{1}-\dot{\varepsilon}_{2}\right) \sin \phi_{r}=2 \dot{r}_{\text {max }} \sin \phi_{r}$

なる圧縮表示式をうる。

以上のことから可容速度は式 (8), (9) を満たし, かつ $S_{V}$ 上で

$$
u_{x}=U_{x}, u_{y}=U_{y}
$$

なるようなものである。ただし式 (8), (9) の0 は応力 解から決まる $S_{1}$ すべり線の方向で与えられるものを用 いる。

一般に可容応力は独立に（または静定の意味で）式 (1)，(2)，(3) を満足すればよく，可容速度も独立的に式 (8), (9), すなわち

$$
\begin{gathered}
\frac{\partial u_{x}}{\partial x}-\frac{\partial u_{y}}{\partial y}+\left(\frac{\partial u_{x}}{\partial y}+\frac{\partial u_{y}}{\partial x}\right) \tan \left(2 \theta+\phi_{r}\right)=0 \\
\frac{\partial u_{x}}{\partial x}\left\{\sin \phi_{r}+\sin \left(2 \theta+\phi_{r}\right)\right\} \\
=\frac{\partial u_{y}}{\partial y}\left\{\sin \phi_{r}-\sin \left(2 \theta+\phi_{r}\right)\right\}
\end{gathered}
$$

と式 (11) を満たせばよい。

可容応力と可容速度が式 (5) によって結ばれるなら, これらが適合した正解となる。可容応力を $\sigma_{i j}{ }^{*}$, 可容速 度を $\boldsymbol{v}^{*}$ と表わすとき, 両者の適合性を式 (5) により調 べるにあたり, 応力解の剛性域で $\dot{\varepsilon}_{i j}{ }^{*}=0$ なることも確 かめねばならない。剛性域でこのことが保証されない解 は不完全解である。

自重のあるときに成り立つ積分表式 (12) は一名仮想 仕事式といわれる。仮想なる意は応力とひずみ速度の間 になんら特別な関係を仮定しないからである。すなわち

$$
\begin{aligned}
& \int\left(\sigma_{x} \dot{\varepsilon}_{x}+\sigma_{y} \dot{\varepsilon}_{y}+2 \tau_{x y} \dot{r}_{x y}\right) d V \\
& \quad=\oint\left(F_{x} U_{x}+F_{y} U_{y}\right) d S-r \int u_{y} d V
\end{aligned}
$$

証明は以下のと抒り。

$$
\begin{aligned}
\int \sigma_{x} \dot{\varepsilon}_{x} d V & =\int_{y_{1}}^{y_{2}}\left[\sigma_{x} u_{x}\right]_{1}^{2} d y-\int u_{x} \frac{\partial \sigma_{x}}{\partial x} d V \\
& =\oint \sigma_{x} u_{x} l d S-\int u_{x} \frac{\partial \sigma_{x}}{\partial x} d V
\end{aligned}
$$

など。他の項についても同様計算して

$$
\begin{aligned}
& \int\left(\sigma_{x} \dot{\varepsilon}_{x}+\sigma_{y} \dot{\varepsilon}_{y}+2 \tau_{x y} \dot{\gamma}_{x y}\right) d V \\
& \quad=\oint\left\{\left(\sigma_{x} l+\tau_{x y} m\right) u_{x}+\left(\sigma_{y} m+\tau_{x y} l\right) u_{y}\right\} d S \\
& -\int\left\{\left(\frac{\partial \sigma_{x}}{\partial x}+\frac{\partial \tau_{x y}}{\partial y}\right) u_{x}+\left(\frac{\partial \sigma_{y}}{\partial y}+\frac{\partial \tau_{x y}}{\partial x}\right) u_{y}\right\} d V
\end{aligned}
$$

图-4

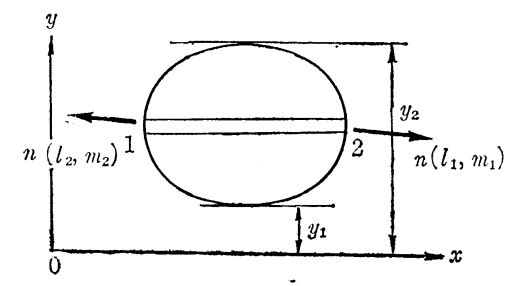

ここで右辺第 1 項に式 (2)，第 2 項に式 (1) を用いる と式 (12) がえられるのである。

\section{3. 下界定理}

本定理は最大塑性仕事の原理または第一変分定理とも いわれるものである。

正解応力, 正解速度を $\sigma_{i j}, v$ とし, $v$ から式 (4) で 導かれるひずみ速度を $\dot{\varepsilon}_{i j}$ とする。 $\dot{\varepsilon}_{i j}$ は $\sigma_{i j}$ と適合す るが， $\dot{\varepsilon}_{i j}$ と適合しない可容応力を $\sigma_{i j}{ }^{*}$ と表わすと

$$
\left.\begin{array}{l}
W=\sigma_{x} \dot{\varepsilon}_{x}+\sigma_{y} \dot{\varepsilon}_{y}+2 \tau_{x y} \dot{\gamma}_{x y}=\sigma_{i j} \dot{\varepsilon}_{i j} \\
W^{*}=\sigma_{x} *_{\dot{\varepsilon}_{x}}+\sigma_{y} * \dot{\varepsilon}_{y}+2 \tau_{x y} * f_{x y}=\sigma_{i j} \dot{\varepsilon}_{i j}
\end{array}\right\}
$$

なる二量を比べたとき

$$
W \geqq W^{*} . .
$$

が証明される。

いま

$$
\left.\begin{array}{l}
\bar{\sigma}_{x}=\sigma_{x}-c_{r} \cot \phi_{r}, \quad \bar{\sigma}_{y}=\sigma_{y}-c_{r} \cot \phi_{r} \\
\bar{\sigma}_{x}^{*}=\sigma_{x} *-c_{r} \cot \phi_{r}, \bar{\sigma}_{y}^{*}=\sigma_{y}^{*}-c_{r} \cot \phi_{r}
\end{array}\right\}
$$

とすると式 (3) は

$$
\left.\begin{array}{l}
\frac{1}{4}\left(\bar{\sigma}_{x}-\bar{\sigma}_{y}\right)^{2}+\tau_{x y}{ }^{2} \leqq \frac{1}{4}\left(\bar{\sigma}_{x}+\bar{\sigma}_{y}\right)^{2} \sin ^{2} \phi_{r} \\
\frac{1}{4}\left(\bar{\sigma}_{x} *-\bar{\sigma}_{y}\right)^{2}+\tau_{x y}{ }^{2} \leqq \frac{1}{4}\left(\bar{\sigma}_{x} *+\bar{\sigma}_{y}{ }^{2 *}\right) \sin ^{2} \phi_{r}
\end{array}\right\}
$$

式 (5), (15) より

$$
\begin{aligned}
& \left.\dot{\varepsilon}_{x}=\frac{\lambda}{2}\left\{\bar{\sigma}_{x}-\bar{\sigma}_{y}\right)-\left(\bar{\sigma}_{x}+\bar{\sigma}_{y}\right) \sin ^{2} \phi_{r}\right\} \\
& \left.\dot{\varepsilon}_{y}=\frac{\lambda}{2}\left\{\bar{\sigma}_{y}-\bar{\sigma}_{x}\right)-\left(\bar{\sigma}_{x}+\bar{\sigma}_{y}\right) \sin ^{2} \phi_{r}\right\} \\
& f_{x y}=\lambda \tau_{x y}
\end{aligned}
$$

だから式 (13)の $W^{*}$ の式に入れて, $\sigma_{x}^{*}, \sigma_{y}{ }^{*}$ を $\bar{\sigma}^{*}, \bar{\sigma}_{y}{ }^{*}$ で改めると

$$
\begin{aligned}
W^{*}= & \frac{\lambda}{2}\left[\left(\bar{\sigma}_{x}-\bar{\sigma}_{y}\right)\left(\bar{\sigma}_{x} *-\bar{\sigma}_{y}{ }^{*}\right)+4 \tau_{x y} \tau_{x y}{ }^{*}\right] \\
& -\frac{\lambda}{2}\left(\bar{\sigma}_{x}+\bar{\sigma}_{y}\right)\left(\bar{\sigma}_{x}{ }^{*}+\bar{\sigma}_{y} *\right) \sin ^{2} \phi_{r} \\
& -\lambda c_{r}\left(\bar{\sigma}_{x}+\bar{\sigma}_{y}\right) \sin \phi_{r} \cos \phi_{r} \ldots \ldots \ldots \ldots . . .
\end{aligned}
$$

ここで Schwarz の不等式

$$
a b+c d \leqq\left(a^{2}+c^{2}\right)^{1 / 2}\left(b^{2}+d^{2}\right)^{1 / 2}
$$

を用いると

$$
\begin{aligned}
W^{*} \leqq & \frac{\lambda}{2}\left[\left(\bar{\sigma}_{x}-\bar{\sigma}_{y}\right)^{2}+4 \tau_{x y}{ }^{2}\right]^{1 / 2} \\
& \times\left[\left(\bar{\sigma}_{x}^{*}-\bar{\sigma}_{y}\right)^{2}+4 \tau_{x y}{ }^{2}\right]^{1 / 2} \\
& -\frac{\lambda}{2}\left(\bar{\sigma}_{x}+\bar{\sigma}_{y}\right)\left(\bar{\sigma}_{x} *+\bar{\sigma}_{y}{ }^{*}\right) \sin ^{2} \phi_{r} \\
& -\lambda c_{r}\left(\bar{\sigma}_{x}+\bar{\sigma}_{y}\right) \sin \phi_{r} \cos \phi_{r} \cdots \cdots . .
\end{aligned}
$$

しかして式 (15) および 図一3 から $\bar{\sigma}_{x}, \bar{\sigma}_{y}, \bar{\sigma}_{x}{ }^{*}, \bar{\sigma}_{y} *$ は皆圧縮応力で負であるから式 (16) は

$0 \leqq\left[\left(\bar{\sigma}_{x}-\bar{\sigma}_{y}\right)^{2}+4 \tau_{x y}{ }^{2}\right]^{1 / 2} \leqslant-\left(\bar{\sigma}_{x}+\bar{\sigma}_{y}\right) \sin \phi_{r}$ $\left.0 \leqq\left[\left(\bar{\sigma}_{x} *-\bar{\sigma}_{y} *\right)^{2}+4 \tau_{x y}{ }^{*}\right]^{1 / 2} \leqslant-\left(\bar{\sigma}_{x}^{*}+\bar{\sigma}_{y} *\right) \sin \phi_{r}\right\}$

したがって式 (18') の右辺第 1,2 項は $\lambda$ の正值条件を 
考えると正とはなりえない。すなわち

$W^{*} \leqq-\lambda c_{r}\left(\bar{\sigma}_{x}+\bar{\sigma}_{y}\right) \sin \phi_{r} \cos \phi_{r}$

一方 $W$ を同様に計算するとき式 (18) に対応し

$$
\begin{aligned}
W= & \frac{\lambda}{2}\left[\left(\bar{\sigma}_{x}-\bar{\sigma}_{y}\right)^{2}+4 \tau_{x y}{ }^{2}-\left(\bar{\sigma}_{x}+\bar{\sigma}_{y}\right)^{2} \sin ^{2} \phi_{r}\right] \\
& \cdots \lambda c_{r}\left(\bar{\sigma}_{x}+\bar{\sigma}_{y}\right) \sin \phi_{r} \cos \phi_{r} \\
= & \frac{\lambda}{2}\left[\left(\sigma_{x} \cdot \sigma_{y}\right)^{2}+4 \tau_{x y}{ }^{2}-\left(\sigma_{x}+\sigma_{y} \cdot 2 c_{r} \cot \phi_{r}\right)^{2}\right. \\
& \left.\times \sin ^{2} \phi_{r}\right] \cdots c_{r}\left(\bar{\sigma}_{x}+\bar{\sigma}_{y}\right) \sin \phi_{r} \cos \phi_{r}
\end{aligned}
$$

であるが, 初めから $\dot{\varepsilon}_{i j} \neq 0$, すなわち塑性変形の状態を 考えているのであるから, 正解応力は式 (3) の等号を満 足している。したがってWの式の右辺第 1 項は $\dot{\varepsilon}_{i j} \neq 0$ のところでは 0 となり

$$
W=-\lambda c_{r}\left(\bar{\sigma}_{x}+\bar{\sigma}_{y}\right) \sin \phi_{r} \cos \phi_{r}
$$

である。式 (19),(20)より式（14）は明らかである。

上に考えた正解 $\sigma_{i j}, \dot{\varepsilon}_{i j}$ は $S_{F}$ 上で $\boldsymbol{F}\left(F_{x}, F_{y}\right), S_{V}$ 上で $\boldsymbol{U}\left(U_{x}, U_{y}\right)$ なる条件に応ずるものであるが， $\sigma_{i j}{ }^{*}$ なる可容応力とつりあう可容表面力は $S_{F}$ 上ではもちろ ん $\boldsymbol{F}$ と一致するが $S_{V}$ では $\boldsymbol{F}^{*}\left(F_{x}, F_{y}{ }^{*}\right)$ なる值をと るものとする。すなわち $S_{V}$ 上で

$$
\sigma_{x}{ }^{*} l+\tau_{x y}{ }^{*} m=F_{x} *, \sigma_{y}{ }^{*} m+\tau_{x y} * l=F_{y} *
$$

である。

式（13）の体積分を考え式（12）を用いると

$$
\begin{aligned}
\int W d V= & \int \sigma_{i j} \dot{\varepsilon}_{i j} d V=\int\left(\sigma_{x} \dot{\varepsilon}_{x}+\sigma_{y} \dot{\varepsilon}_{y}\right. \\
& \left.+2 \tau_{x y} t_{x y}\right) d V \\
= & \int_{S_{F}}\left(F_{x} u_{x}+F_{y} u_{y}\right) d S \\
& +\int_{S_{V}}\left(F_{x} U_{x}+F_{y} U_{y}\right) d S-r \int u_{y} d V \\
\int W^{*} d V= & \int_{i_{j}} * \dot{\varepsilon}_{i j} d V=\int\left(\sigma_{x} *_{\dot{\varepsilon}_{x}}+\sigma_{y}{ }^{*} \dot{\varepsilon}_{y}\right. \\
& \left.+2 \tau_{x y} * f_{x y}\right) d V \\
= & \int_{S_{F}}\left(F_{x} u_{x}+F_{y} u_{y}\right) d S \\
& +\int_{S_{V}}\left(F_{x} * U_{x}+F_{y} * U_{y}\right) d S-r \int u_{y} d V
\end{aligned}
$$

したがって式 (14) によって

$$
\int_{S_{V}}\left(F_{x} U_{x}+F_{y} U_{y}\right) d S \geqq \int_{S_{V}}\left(F_{x} * U_{x}+F_{y} * U_{y}\right) d S
$$

これが下界定理であって，土のように摩擦抵抗および 自重の無視しえない剛塑性体についても金属塑性論と同 じ結論がえられた。

式 (22) は境界面 $S_{V}$ 上で速度条件が与えられたとき, $r, c_{r}, \phi_{r}$ 材における正解の表面力 $\boldsymbol{F}$ のなす仕事率は, 同じ $S_{V}$ 上で他のいかなる可容表面力 $F^{*}$ のなす仕事率 よりも小さくなりえないことを述べている。すなわち正 解が知られなくても可容応力解がえられればそれは正解 を越えることはない，才なわち正解の一つの下界が求め られたことを意味する。

いままでの議論で応力や速度の不連続性は考慮しなか ったが，これらの不連続線がある場合を吟味する。まず 応力の不連続線上ではひずみ速度はすべて消失し $\dot{\boldsymbol{\varepsilon}}_{i j} \equiv 0$ なる性質 (山口, 1967) を考えると, 応力の不連続線の 存在は下界定理式 (22) の成立を妨げるものではないこ とが明らかとなる。このことは以下のように直接証明も

图-5

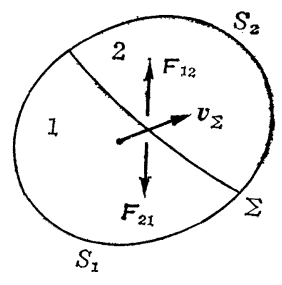

できる。

応力の不連続線を $\Sigma$ とする とこの上では速度が連続である ことが知られている（山口， 1967)ので，これを 1,2 両域に ついて $v_{\Sigma}$ とする。また応力成 分に不連続があっても，力のつ りあい関係から $\Sigma$ 上での合力 は当然連続であり, $\boldsymbol{F}_{12}+\boldsymbol{F}_{21}=0$ となる。1, 2 両域に 式（12）を適用すると

$$
\begin{aligned}
\int \sigma_{i j} \dot{\boldsymbol{\varepsilon}}_{i j} d V_{1}= & \int(\boldsymbol{F} \cdot \boldsymbol{v}) d S_{1} \\
& +\int\left(\boldsymbol{F}_{12} \cdot \boldsymbol{v}_{\Sigma}\right) d \Gamma-\gamma \int u_{y} d V_{1} \\
\int \sigma_{i j} \dot{\varepsilon}_{i j} d V_{2}= & \int(\boldsymbol{F} \cdot \boldsymbol{v}) d S_{2} \\
& +\int\left(\boldsymbol{F}_{21} \cdot \boldsymbol{v}_{\Sigma}\right) d \Gamma-r \int u_{y} d V_{2}
\end{aligned}
$$

ここに（）はスカラー積を意味する。

二式を加え

$$
\begin{aligned}
\int \sigma_{i j} \dot{\boldsymbol{\varepsilon}}_{i j} d V= & \oint(\boldsymbol{F} \cdot \boldsymbol{v}) d S-\gamma \int u_{y} d V=\int_{S_{F}}(\boldsymbol{F} \cdot \boldsymbol{v}) d S \\
& +\int_{S_{A}}(\boldsymbol{F} \cdot \boldsymbol{U}) d S-\gamma \int u_{y} d V
\end{aligned}
$$

同様

$$
\begin{aligned}
\int \sigma_{i j} * \dot{\varepsilon}_{i j} d V= & \int_{S_{F}}(\boldsymbol{F} \cdot \boldsymbol{v}) d S \\
& +\int_{S_{V}}\left(\boldsymbol{F}^{*} \cdot \boldsymbol{U}\right) d S-r \int u_{y} d V
\end{aligned}
$$

ところで至るところで式 (14) が成り立つから

$$
\int \sigma_{i j} \dot{\varepsilon}_{i j} d V \geqq \int \sigma_{i j} *_{\dot{\varepsilon}_{i j}} d V
$$

したがって前二式から再び式 (22) がえられる。

速度が不連続であるとき，その不連続線を $\Gamma$ とし，雨 側の速度の $\Gamma$ に垂直および平行な成分を 図一6に示すよ うなものとする。なお $\Gamma$ 上の応力 $\sigma_{\Gamma}, \tau_{\Gamma}$ は力のつりあ いからもちろん連続である。さて領域 1 に仮想仕事の式 (12)を適用すると,

$$
\text { 図一6 }
$$

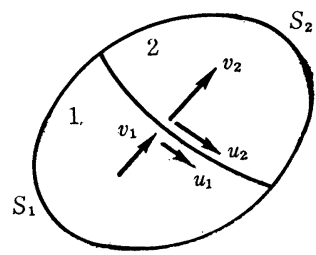

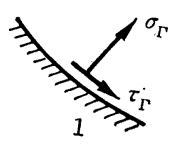




$$
\begin{aligned}
\int \sigma_{i j} \dot{\boldsymbol{\varepsilon}}_{i j} d V_{1}= & \int(\boldsymbol{F} \cdot \boldsymbol{v}) d S_{1} \\
& +\int\left(\boldsymbol{F}_{\Gamma} \cdot \boldsymbol{v}_{\Gamma_{1}}\right) d \Gamma-\gamma \int u_{y} d V_{1} \\
= & \int(\boldsymbol{F} \cdot \boldsymbol{v}) d S_{1} \\
& +\int\left(\sigma_{\Gamma} v_{1}+\tau_{\Gamma} u_{1}\right) d I^{\prime} \cdots \gamma \int u_{y} d V_{1}
\end{aligned}
$$

同様に

$$
\begin{aligned}
\int \sigma_{i j} \dot{\varepsilon}_{i j} d V_{2}= & \int(\boldsymbol{F} \cdot \boldsymbol{v}) d S_{2} \\
& -\int\left(\sigma_{\Gamma} v_{2}+\tau_{\Gamma} u_{2}\right) d \Gamma-r \int u_{y} d V_{2}
\end{aligned}
$$

これらを加え

$$
\begin{aligned}
\int \sigma_{i j} \dot{\boldsymbol{\varepsilon}}_{i j} d V= & \oint(\boldsymbol{F} \cdot \boldsymbol{v}) d S \\
& -\int\left(\sigma_{\Gamma} \delta v+\tau_{\Gamma} \delta u\right) d \Gamma-\gamma \int u_{y} d V
\end{aligned}
$$

ただし，

$$
\delta u=u_{2}-u_{1}, \delta v=v_{2}-v_{1}
$$

ここで $\left(\sigma_{\Gamma} \delta v+\tau_{\Gamma} \delta u\right)$ は不連続線 $\Gamma$ 上の単位面積当 りのエネルギーの消散率を表わしている。その理由を述

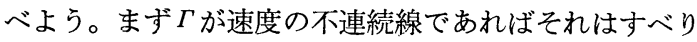
線以外のものでありえない。したがって不連続線に沿っ ての伸びひずみ速度はない（式 (30) または山口，1959）。 不連続線の幅, すなわち遷移領域の厚さを $t$ とし, 不連 続線に垂直な方向を $n$ とすると直交座標 $s n$ に関するひ ずみ速度成分は 図一6 および式 (23) の記号を用いて

$$
\dot{\varepsilon}_{s}=0, \dot{\varepsilon}_{n}=\frac{\delta v}{t}, 2 \dot{\gamma}_{s n}=\frac{\delta u}{t}+\frac{\partial v}{\partial s} \div \frac{\delta u}{t}
$$

となる,ここで不連続性から $\delta u / t \gg \partial v / \partial s$ に注意した い。したがって不連続帯の単位体積当りの塑性仕事率は

$$
\begin{aligned}
W_{s} & =\sigma_{n} \dot{\varepsilon}_{n}+\sigma_{s} \dot{\varepsilon}_{s}+2 \dot{\gamma}_{s n} \tau_{s n} \\
& =\sigma_{\Gamma} \dot{\varepsilon}_{n}+2 \tau_{\Gamma} \dot{\gamma}_{s n}=\frac{\sigma_{\Gamma} \delta v+\tau_{\Gamma} \delta u}{t}
\end{aligned}
$$

で, $W_{s} \cdot t=\sigma_{\Gamma} \delta v+\tau_{\Gamma} \delta u$ は $\Gamma$ 上の単位面積当りの塑性 仕事率となる。

よって式 (23) は

$$
\begin{aligned}
\int \sigma_{i j} \dot{\varepsilon}_{i j} d V= & \int_{S_{F}}(\boldsymbol{F} \cdot \boldsymbol{v}) d S \\
& +\int_{S_{V}}(\boldsymbol{F} \cdot \boldsymbol{U}) d S-r \int u_{y} d V \\
& -\int\left(\sigma_{s} \dot{\varepsilon}_{s}+\sigma_{n} \dot{\varepsilon}_{n}+2 \tau_{s n} \boldsymbol{\psi}_{s n}\right) t d \Gamma
\end{aligned}
$$

同様に

$$
\begin{aligned}
\int \sigma_{i j} *_{\dot{\boldsymbol{i}}_{i j}} d V= & \int_{\boldsymbol{S}_{\boldsymbol{F}}}(\boldsymbol{F} \cdot \boldsymbol{v}) d S \\
& +\int_{S_{V}}\left(\boldsymbol{F}^{*} \cdot \boldsymbol{U}\right) d S-\gamma \int u_{y} d V \\
& -\int\left(\sigma_{s} \dot{\varepsilon}_{s}+\sigma_{n}{ }^{*} \dot{\varepsilon}_{n}+2 \tau_{s n}{ }^{* \boldsymbol{f}_{s n}}\right) t d \Gamma
\end{aligned}
$$

他方, 式 (14) は一点で成立りつ一般的関係だから

$$
\sigma_{s}{ }^{*} \dot{\varepsilon}_{s}+\sigma_{n}{ }^{*} \dot{\varepsilon}_{n}+2 \tau_{s n}{ }^{*} \dot{\tau}_{s n} \leqq \sigma_{s} \dot{\varepsilon}_{s}+\sigma_{n} \dot{\varepsilon}_{n}+2 \tau_{s n} t_{s n}
$$

さらに,

$$
\sigma_{i j} \dot{\varepsilon}_{i j} \geqq \sigma_{i j}{ }^{*} \dot{\varepsilon}_{i j}
$$

であるので式 $\left(23^{\prime}\right)$ より

$$
\begin{aligned}
\int_{S_{V}}(\boldsymbol{F} \cdot \boldsymbol{U}) d S^{\prime}-\int_{S_{V}}(\boldsymbol{F} * \cdot \boldsymbol{U}) d S \\
=\int\left(\sigma_{i j} \dot{\varepsilon}_{i j} \cdots \sigma_{i j}{ }^{*} \dot{\boldsymbol{\varepsilon}}_{i j}\right) d V \\
\quad+\int\left\{\sigma_{s} \dot{\varepsilon}_{s}+\sigma_{n} \dot{\varepsilon}_{n}+2 \tau_{s n} \dot{T}_{s n}\right) \\
\left.\quad-\left(\sigma_{s} \dot{\varepsilon}_{s}+\sigma_{n} \dot{\varepsilon}_{n}+2 \tau_{s n}{ }^{*} \dot{f}_{s n}\right)\right\} t d \Gamma>0
\end{aligned}
$$

が結論され下界定理 (22) が証明された。

以上によって土の塑性論でも応力や速度の不連続性に 関係なく下界定理がつねに式 (22) の形で成り立つ。

\section{4. 上界定理}

正解を $\left(\sigma_{i j}, \dot{\varepsilon}_{i j}\right)$ とし, 可容速度 $\boldsymbol{v}^{*}$ から導かれるひ ずみ速度を $\dot{\varepsilon}_{i j}{ }^{*}$ とする。この $\boldsymbol{v}^{*}$ は前に述べたごとく 等方, 圧縮両式と境界面 $S_{V}$ 上で $\boldsymbol{v}^{*}=\boldsymbol{U}$ の条件とを満 たせばよい。

$\dot{\boldsymbol{\varepsilon}}_{i j}$ * と適合する応力を $\sigma_{i j} *$ とすると, これらは

$$
\begin{aligned}
\dot{\varepsilon}_{i j} *= & \lambda * \partial f^{*} / \partial \sigma_{i j}{ }^{*} \\
f^{*}= & \frac{1}{4}\left(\sigma_{x}^{*} \cdots \sigma_{y}\right)^{2}+\tau_{x y}{ }^{* 2} \\
& \quad-\left(c_{r} \cos \phi_{r}-\frac{\sigma_{x} *+\sigma_{y} *}{2} \sin \phi_{r}\right)^{2} \\
\lambda^{*}>0 & \left(f^{*}=0\right), \lambda^{*}=0\left(f^{*}<0\right)
\end{aligned}
$$

の関係がある。

ここで式 (14) に対応して

$$
\sigma_{i j} \cdot \dot{\varepsilon}_{i j}{ }^{*} \leqq \sigma_{i j}{ }^{*} \cdot \dot{\varepsilon}_{i j} * \ldots
$$

が証明できる。

すなわち式 (25) から式 (18) と同様な

$$
\sigma_{i j} \dot{\varepsilon}_{i j} *=\frac{\lambda *}{2}\left[\left(\bar{\sigma}_{x}-\bar{\sigma}_{y}\right)\left(\bar{\sigma}_{x} *-\bar{\sigma}_{y}{ }^{*}\right)+4 \tau_{x y} \tau_{x y}{ }^{*}\right]
$$

$$
\begin{aligned}
& -\frac{\lambda *}{2}\left(\bar{\sigma}_{x}+\bar{\sigma}_{y}\right)\left(\bar{\sigma}_{x}+\bar{\sigma}_{y} *\right) \sin ^{2} \phi_{r} \\
& -\lambda^{*} c_{r}\left(\bar{\sigma}_{x} *+\bar{\sigma}_{y} *\right) \sin \phi_{r} \cos \phi_{r}
\end{aligned}
$$

これから下界定理の場合と同様

$$
\sigma_{i j} \dot{\varepsilon}_{i j}{ }^{*} \leqq-\lambda{ } c_{r}\left(\bar{\sigma}_{x} *+\bar{\sigma}_{y} *\right) \sin \phi_{r} \cos \phi_{r}=\sigma_{i j} * \dot{\varepsilon}_{i j} *
$$

で式 (26) が成り立つ。

仮想仕事式 (12) を用いるなら

$$
\begin{aligned}
\int \sigma_{i j} \dot{\boldsymbol{\varepsilon}}_{i j} * d V= & \oint\left(\boldsymbol{F} \cdot \boldsymbol{v}^{*}\right) d S-r \int u_{\boldsymbol{y}} * d V \\
= & \int_{S_{\boldsymbol{F}}}\left(\boldsymbol{F} \cdot \boldsymbol{v}^{*}\right) d S \\
& +\int_{S_{V}}(\boldsymbol{F} \cdot \boldsymbol{U}) d S_{V}-r \int u_{\boldsymbol{y}} * d V
\end{aligned}
$$

また

$$
\int \sigma_{i j} * \dot{\varepsilon}_{i j} * d V=-c_{r} \sin \phi_{r} \cos \phi_{r} \int \lambda^{*}\left(\bar{\sigma}_{x} *+\bar{\sigma}_{y} *\right) d V
$$

だから式 (26) より 


$$
\begin{array}{r}
\int_{S_{V}}(\boldsymbol{F} \cdot \boldsymbol{U}) d S \leqq r \int u_{y} * d V-\int_{S_{F}}\left(\boldsymbol{F} \cdot \boldsymbol{v}^{*}\right) d S \\
-c_{r} \sin \phi_{r} \cos \phi_{r} \int \lambda *\left(\overline{\boldsymbol{\sigma}}_{x} *+\overline{\boldsymbol{\sigma}}_{y} *\right) d V \cdots
\end{array}
$$

一方, 式 (25) より式 (10) を参照して

$$
\dot{\boldsymbol{\varepsilon}}_{x} *+\dot{\boldsymbol{\varepsilon}}_{y} * \equiv \dot{\boldsymbol{\varepsilon}}_{1} \uparrow \dot{\boldsymbol{\varepsilon}}_{2} *=2 \dot{\gamma}_{\mathrm{max}} *_{\sin } \phi_{r}
$$

$$
=\cdots \cdot \lambda\left(\bar{\sigma}_{x} *+\bar{\sigma}_{y} *\right) \sin ^{2} \phi_{r}
$$

であるので式 (26) は

$$
\begin{aligned}
& \int_{S_{V}}(\boldsymbol{F} \cdot \boldsymbol{U}) d S \leqq r \int_{y} u_{y} d V \cdots \int_{S_{F}}\left(\boldsymbol{F} \cdot \boldsymbol{v}^{*}\right) d S \\
& \quad+2 c_{r} \cos \phi_{r} \int t_{\max } * d V \quad \ldots \ldots \ldots \ldots \ldots \ldots \ldots
\end{aligned}
$$

となり，これが所求の上界定理である。

適合系 $\left(\sigma_{i j}{ }^{*}, \dot{e}_{i j}\right)$ に不連続性があるときの上界定理を 調べる。応力の不連続線上では $\dot{\varepsilon}_{i j}{ }^{*}$ が消失するので $\Sigma^{*}$ 上の面積分は式 (28) に影響を与えないが， $\boldsymbol{v}^{*}$ に不連続 性があれば上界定理は修正される。

\section{図一7}
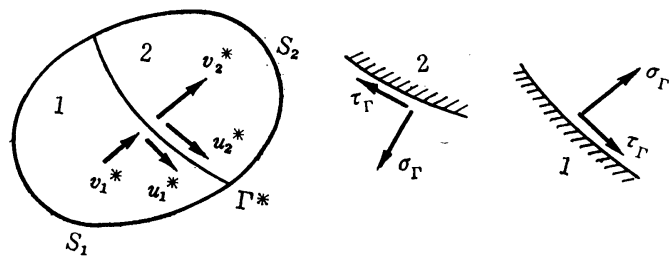

$\Gamma^{*}$ を速度の不連続線とすると式 (23) 同様

$$
\begin{gathered}
\int \sigma_{i j} \dot{\boldsymbol{e}}_{i j} * d V=\int_{S_{\boldsymbol{F}}}\left(\boldsymbol{F} \cdot \boldsymbol{v}^{*}\right) d S+\int_{S_{V}}(\boldsymbol{F} \cdot \boldsymbol{U}) d S \\
-\int\left(\sigma_{\Gamma^{\delta}} \delta v^{*}+\tau_{\Gamma^{\delta}} u^{*}\right) d \Gamma^{*}-\gamma \int u_{\boldsymbol{y}}{ }^{*} d V
\end{gathered}
$$

ただし，

$$
\delta u^{*}=u_{2}^{*}-u_{1}^{*}, \delta v^{*}=v_{2}^{*}-v_{1}^{*}
$$

上式左辺は式 (26) によって

$$
\begin{aligned}
& \int \sigma_{i j} *_{\dot{\varepsilon}_{i j}} * d V=-c_{r} \sin \phi_{r} \cos \phi_{r} \\
& \quad \times \int \lambda *\left(\bar{\sigma}_{x} *+\bar{\sigma}_{y} *\right) d V=2 c_{r} \cos \phi_{r} \int t_{\max } * d V
\end{aligned}
$$

より大きくない。ゆえに

$$
\begin{aligned}
& \int_{S_{V}}(\boldsymbol{F} \cdot \boldsymbol{U}) d S \leqslant r \int u_{y} * d V-\int_{S_{F}}\left(\boldsymbol{F} \cdot \boldsymbol{v}^{*}\right) d S \\
& \quad+2 c_{r} \cos \phi_{r} \int \boldsymbol{t}_{\max }{ }^{*} d V \\
& \quad+\int\left(\sigma_{\Gamma} \delta v^{*}+\tau_{\Gamma^{\delta}} u^{*}\right) d \Gamma^{*} \ldots \ldots \ldots \ldots \ldots \ldots
\end{aligned}
$$

上式末項は速度の不連続線上で消散される仕事率で正 量であるが式 (26) より

$$
\begin{aligned}
& \int\left(\sigma_{\Gamma^{\delta}} \delta v^{*}+\tau_{\Gamma^{\delta}} u^{*}\right) d \Gamma^{*} \\
& =\int\left(\sigma_{n} \dot{\boldsymbol{e}}_{n}{ }^{*}+\sigma_{s} \dot{\boldsymbol{e}}_{s} *+2 \tau_{n s} \boldsymbol{t}_{n s}{ }^{*}\right) t^{*} d \Gamma^{*} \\
& <\int\left(\sigma_{n}{ }^{*} \dot{\boldsymbol{\varepsilon}}_{n}{ }^{*}+\sigma_{s}{ }^{*} \dot{\boldsymbol{\varepsilon}}_{s} *+2 \tau_{n s} t_{n s}{ }^{*}\right) t^{*} d \Gamma^{*} \\
& =\int\left(\sigma_{\Gamma}^{*} \delta v^{*}+\tau_{\Gamma}{ }^{*} \delta u^{*}\right) d \Gamma^{*}
\end{aligned}
$$

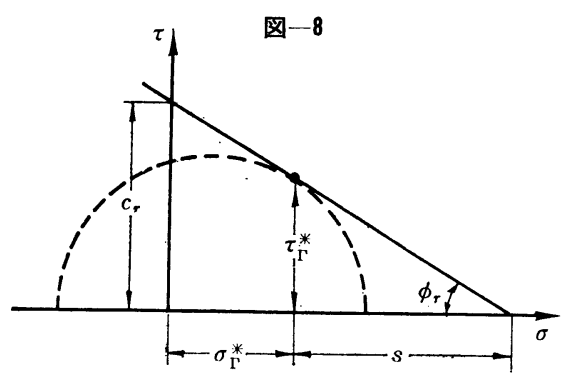

いま $I^{*}$ なる不連続線すなわちすべりの遷移域内で帯 域に平行および垂直な二方向 $s, n$ を $x y$ 軸にとると式 (7) で $\theta=0$ とすることにより

$$
\begin{aligned}
& \dot{\boldsymbol{\varepsilon}}_{s}{ }^{*}=0, \dot{\boldsymbol{\varepsilon}}_{n}^{*}=2 \lambda^{*} p^{*} \sin ^{2} \phi_{r}, \\
& 2 \dot{\gamma}_{s n}{ }^{*}=2 \lambda^{*} p^{*} \sin \phi_{r} \cos \phi_{r} .
\end{aligned}
$$

これを式 (24) とくらべて

$\delta v^{*}=\delta u^{*} \tan \phi_{r}$

また $\sigma_{\Gamma}^{*}, \tau_{\Gamma}^{*}$ は 図一8に示すように,

$$
\left.\begin{array}{l}
\tau_{\Gamma}^{*}=s \tan \phi_{r} \\
\sigma_{\Gamma}^{*}=c_{r} \cot \phi_{r}-s
\end{array}\right\}
$$

だから式 (31) を考えて

$$
\sigma_{\Gamma} * \delta v^{*}+\tau_{\Gamma} * \delta u^{*}=c_{r} \delta u^{*}
$$

式 (31),(32) は Drucker, Prager がすでに示したもの であるが，ここでは別の角度から証明した（Drucker， Prager, 1952)。

以上によって結局, 式 (29) は

$$
\begin{aligned}
& \int_{S_{V}}(\boldsymbol{F} \cdot \boldsymbol{U}) d S \leqslant r \int u_{y} * d V-\int_{S_{F}}\left(\boldsymbol{F} \cdot \boldsymbol{v}^{*}\right) d S \\
& \quad+2 c_{r} \cos \phi_{r} \int \boldsymbol{t}_{\max } * d V+c_{r} \int \delta u^{*} d \Gamma^{*} \ldots
\end{aligned}
$$

これが適合系速度に不連続があるときの上界定理であ る。

式 (22) と式 (33) 功

$$
\begin{aligned}
& \int_{S_{V}}(\boldsymbol{F} * \cdot \boldsymbol{U}) d S \leqslant \int_{S_{V}}(\boldsymbol{F} \cdot \boldsymbol{U}) d S \\
& \quad \leqslant r \int u_{y} * d V-\int_{S_{F}}\left(\boldsymbol{F} \cdot \boldsymbol{v}^{*}\right) d S \\
& \quad+2 c_{r} \cos \phi_{r} \int \boldsymbol{t}_{\max } * d V+c_{r} \int \delta u^{*} d \Gamma^{*}
\end{aligned}
$$

これによって可容応力の表面力のなす仕事または可容 速度に対して正解のなす仕事の大小関係が求められた。

\section{5. 解の唯一性}

物体の境界面の一部 $S_{F}$ 上で表面力 $\boldsymbol{F}$, 残りの $S_{V}$ 上 で速度 $\boldsymbol{U}$ が与えられたとき, 塑性変形をする領域内で は正解応力がただ一通りに決まる。

仮に二つの正解 $\left(\sigma_{i j}, \dot{\varepsilon}_{i j}\right),\left(\sigma_{i j}{ }^{\circ}, \dot{\varepsilon}_{i j}{ }^{\circ}\right)$ がえられたと しよう。

$$
\begin{aligned}
& \int\left(\sigma_{i j}-\sigma_{i j}{ }^{\circ}\right)\left(\dot{\boldsymbol{\varepsilon}}_{i j}-\dot{\boldsymbol{\varepsilon}}_{i j}{ }^{\circ}\right) d V=\int \sigma_{i j} \dot{\boldsymbol{\varepsilon}}_{i j} d V \\
& +\int \sigma_{i j} \dot{\boldsymbol{\varepsilon}}_{i j}{ }^{\circ} d V-\int \sigma_{i j} \dot{\boldsymbol{\varepsilon}}_{i j}{ }^{\circ} d V-\int \sigma_{i j}{ }^{\circ} \dot{\boldsymbol{\varepsilon}}_{i j} d V
\end{aligned}
$$


に式（12）を適用すると

$$
\begin{aligned}
& \int\left(\sigma_{i j}-\sigma_{i j}{ }^{\circ}\right)\left(\dot{\boldsymbol{\varepsilon}}_{i j}-\dot{\boldsymbol{\varepsilon}}_{i j}{ }^{\circ}\right) d V=\int_{S_{\boldsymbol{F}}}(\boldsymbol{F} \cdot \boldsymbol{v}) d S \\
& +\int_{S_{V}}(\boldsymbol{F} \cdot \boldsymbol{U}) d S-\gamma \int u_{y} d V-\int\left(\sigma_{i j} \dot{\varepsilon}_{i j}\right) t d \Gamma \\
& +\int_{S_{F}}\left(\boldsymbol{F}^{\circ} \cdot \boldsymbol{v}^{\circ}\right) d S+\int_{S_{V}}\left(\boldsymbol{F}^{\circ} \cdot \boldsymbol{U}^{\circ}\right) d S-\gamma \int u_{\boldsymbol{y}}^{\circ} d V \\
& -\int\left(\sigma_{i j}{ }^{\circ} \dot{\boldsymbol{\varepsilon}}_{i j}{ }^{\circ}\right) t^{\circ} d \Gamma^{\circ}-\int_{S_{F}}\left(\boldsymbol{F} \cdot \boldsymbol{v}^{\circ}\right) d S \\
& -\int_{S_{V}}\left(\boldsymbol{F} \cdot \boldsymbol{U}^{\circ}\right) d S+r \int u_{y}{ }^{\circ} d V+\int\left(\sigma_{i j} \dot{\varepsilon}_{i j}{ }^{\circ}\right) t^{\circ} d \Gamma^{\circ} \\
& -\int_{S_{\boldsymbol{F}}}\left(\boldsymbol{F}^{\circ} \cdot \boldsymbol{v}\right) d S-\int_{S_{V}}\left(\boldsymbol{F}^{\circ} \cdot \boldsymbol{U}\right) d S+r \int u_{y} d V \\
& +\int\left(\sigma^{\circ}{ }_{i j} \dot{\varepsilon}_{i j}\right) t d \Gamma
\end{aligned}
$$

ただし二つの正解に対する速度不連続面は一般に異な るから $\Gamma, \Gamma^{\circ}$ とし遷移域厚さも $t, t^{\circ}$ とした。また二つの 正解に対し $S_{F}$ 上で $\boldsymbol{F}=\boldsymbol{F}^{\circ}, S_{V}$ 上で $\boldsymbol{U}=\boldsymbol{U}^{\circ}$ あるので,

$$
\begin{aligned}
& \int\left(\sigma_{i j}-\sigma_{i j}{ }^{\circ}\right)\left(\dot{\varepsilon}_{i j}-\dot{\varepsilon}_{i j}{ }^{\circ}\right) d V \\
& =\int\left\{\left(\sigma_{i j}{ }^{\circ}-\sigma_{i j}\right) \dot{\varepsilon}_{i j}\right\} t d \Gamma \\
& \quad+\int\left\{\left(\sigma_{i j}-\sigma_{i j}{ }^{\circ}\right) \dot{\varepsilon}_{i j}\right\} t^{\circ} d \Gamma^{\circ}
\end{aligned}
$$

上式の左辺は式 (14),(26) などにより

$$
\left(\sigma_{i j}-\sigma_{i j}{ }^{\circ}\right) \dot{\boldsymbol{\varepsilon}}_{i j} \geqq 0,\left(\sigma_{i j}{ }^{\circ}-\sigma_{i j}\right) \dot{\boldsymbol{\varepsilon}}_{i j}{ }^{\circ} \geqq 0
$$

だから負となりえない。

他方右辺においては

$$
\left(\sigma_{i j}{ }^{\circ}-\sigma_{i j}\right) \dot{\boldsymbol{\varepsilon}}_{i j} \leqq 0,\left(\sigma_{i j}-\sigma_{i j}{ }^{\circ}\right) \dot{\boldsymbol{\varepsilon}}_{i j}{ }^{\circ} \leqq 0
$$

で正となりえない。

式(34) の等号が成り立つためには $\dot{\varepsilon}_{i j} \neq 0, \dot{\varepsilon}_{i j}{ }^{\circ} \neq 0$ である限り，

$$
\sigma_{i j} \equiv \sigma_{i j}{ }^{\circ}
$$

が必要十分である。すなわち塑性域 $\left(\dot{\boldsymbol{\varepsilon}}_{i j}, 0\right)$ での応力 解の一意性が示された。

\section{6. 応用例}

（1）直立のり面の安定高さを調べよう。式 (14) に よると $\sigma_{i j} \dot{\varepsilon}_{i j} \geqslant \sigma_{i j}{ }^{*} \dot{\varepsilon}_{i j}$ であるが応力とひずみ増分の符 号は等しいと考えてよいので可容応力解と正解応力の絶 対值を比べたとき前者は後者より大きくはありえない。 これはまた可容応力解が正解応力の下界であることにほ かならぬ。したがって可容応力を生ぜしめるのり高は正 しい自立高の值をこえることはない。

図一9についてつりあい方程式と表面で自由なる境界 条件を満たす可容応力の一つは

$$
\sigma_{x}{ }^{*}=0, \sigma_{y} *=r\left(y-H^{*}\right), \tau_{x y}{ }^{*}=0
$$

でこれらは主応力となる。すなわち $\sigma_{1}{ }^{*}=\sigma_{x}>\sigma_{2}{ }^{*}=\sigma_{y}$ で 最大 Mohr 円は $y=0$ で生じ $\sigma_{1}{ }^{*}=0, \sigma_{2}{ }^{*}=-r H^{*}$ とな る。降伏が生じるのは $y=0$ であって式 (3) で $f \rightarrow f^{*}$ =0とした式

$$
\sigma_{1}^{*}-\sigma_{2}^{*}=2 c_{r} \cos \phi_{r}-\left(\sigma_{1}^{*}+\sigma_{2}^{*}\right) \sin \phi_{r}
$$

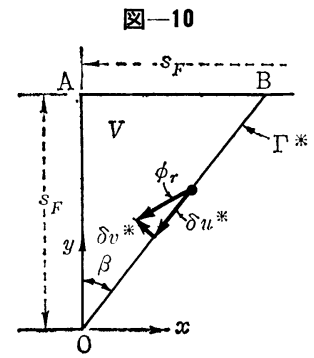

に入れて

$$
H^{*}=\frac{2 c \cos \phi_{r}}{r\left(1-\sin \phi_{r}\right)}=\frac{2 c_{r}}{r} \tan \left(\frac{\pi}{4}+\frac{\phi_{r}}{2}\right)
$$

となり実際の自立高は

$$
H>\frac{2 c_{r}}{r} \tan \left(\frac{\pi}{4}+\frac{\phi_{r}}{2}\right)
$$

つぎに上界定理を適用するため, 図一10に示すような 傾角 $\beta$ の直線を仮定し，その上で可容速度が不連続とす る。すなわち $\Gamma^{*}$ 線はすべり線であって $\triangle \mathrm{OAB}$ 内では $\dot{\gamma}_{\text {max }}{ }^{*} \equiv 0$ ，すなわち剛性域とする。これは境界面がす べて応力だけの条件で規定されていて $\boldsymbol{U}$ は何であって もよいことから，上述の速度は可容のものとなるのであ る。

すべり線 $\Gamma^{*}$ 上では要素の速度は式 (31) に示すごと くであるので 図一10 に画くように $\Gamma^{*}$ と $\phi_{r}$ をなす方 向であり，この速度は $V \sim \triangle \mathrm{OAB}$ 内で共通となる。し たがって

$$
\begin{aligned}
u_{y}^{*} & =-\sqrt{\delta u^{* 2}+\delta v^{* 2}} \cos \left(\beta+\phi_{r}\right) \\
& =-\delta u^{*} \sqrt{1+\tan ^{2} \phi_{r}} \cos \left(\beta+\phi_{r}\right) \\
& =-\frac{\delta u^{*}}{\cos \phi_{r}} \cos \left(\beta+\phi_{r}\right)
\end{aligned}
$$

さて式 (33) で $S_{V}=0, \boldsymbol{F}=0$ を考えると

$$
\begin{aligned}
& r \int u_{y} * d V+c_{r} \int \delta u^{*} d \Gamma^{*} \geqq 0 \\
& \therefore c_{r} \int d \Gamma^{*} \geqq \frac{r \cos \left(\beta+\phi_{r}\right)}{\cos \phi_{r}} \int d V
\end{aligned}
$$

しかして，

$$
\begin{aligned}
& \int d \Gamma^{*}=\overline{\mathrm{OB}}=\frac{H}{\cos \beta}, \int d V=\triangle \mathrm{OAB}=\frac{H^{2}}{2} \tan \beta \\
& \therefore H \leqq \frac{2 c_{r} \cos \phi_{r}}{r \sin \beta \cos \left(\beta+\phi_{r}\right)}
\end{aligned}
$$

自立高 $H$ は $\beta$ の值に関せず上式右辺より常に小さい ので, 右辺の最小值を求めるとそれは $\beta=\pi / 4-\phi_{r} / 2$ で 生じ

$$
H \leqq \frac{4 c_{r}}{r} \tan \left(\frac{\pi}{4}+\frac{\phi_{r}}{2}\right)
$$

i)，iii）によって自立高 $H$ の範囲が知れた。これらは Drucker, Prager の崩壊定理から導かれた結果と同じで ある。

領域 $\mathrm{OAB}$ が剛体的にすべりうるもう一つの可能な不 連続線は $\mathrm{OB}$ が対数螺線の場合である。すなわち $L$ を 極とする対数螺線 
$r=r_{0} \exp \left(\theta \tan \phi_{r}\right)$

図-11

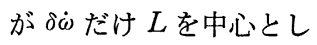
て剛体的に回転すると， $\Gamma^{*}$ 上の一点 $r$ での全変 位速度 $\delta \bar{v}$ は $r \delta \dot{\omega}$ であ り,その方向は $r$ に直角 だから $\Gamma^{*} に$ 平行および 垂直な $\delta u^{*}, \delta v^{*}$ の二成 分は式 (31) を満足する ことになるためである。

ii）はこの場合にもそ

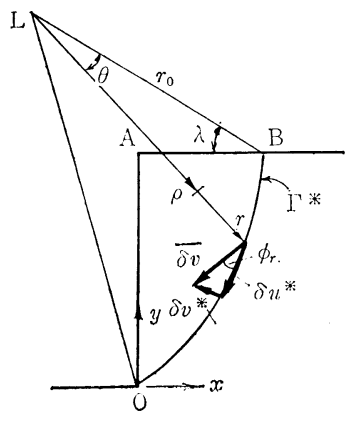

のまま成り立つが，任意点を $(\rho, \theta)$ とすると $u_{y}^{*}=$ $\rho \delta \dot{(i)} \cos (\alpha+\theta)$ だから

$$
r \int u_{y} * d V=-\delta \dot{\omega} \int \rho \cos (\alpha+\theta) r d V
$$

この右辺は面積 $\mathrm{OAB}$ に働く重力の極 $L$ に関する滑 動モーメント $\left(M_{D}\right)$ に等しい。また,

$$
c_{r} \int \delta u^{*} d \Gamma^{*}=\delta \dot{\omega} \int r \cos \phi_{r} c_{r} d \Gamma^{*}
$$

は容易に理解されるように， $\Gamma^{*}$ に働く粘着力の $L$ に関 するモーメントである。摩擦抵抗の成分に寄与する力は すべて $L$ を通るため $L$ でのモーメントは消失し, 上式 は $\Gamma^{*}$ に働く全せん断抵抗のモーメントすなわち $M_{R}$ と なる。よって ii) は

$$
\int_{M_{D} \leqq M_{R}} \rho \cos (\alpha+\theta) r d V \leqslant \int \gamma c_{r} \cos \phi_{r} d \Gamma^{*} \text { または...................... }
$$

iv）を実線の場合に計算し $H$ のよりよい近似值を求 めることができるが，このような計算は Taylor (1937) によってすでに行われていてその結果によると iii) の右 辺の值が約 4 5\% ほど小さくなることが確かめられて いる。

（2）土圧の例を考えよう。OA を壁面としてまず上 界定理を適用する。OA 面は $S_{F}$ でそこでの接触応力を $F_{x}, F_{y}$ (正解值) とすると, 壁の粗さ角が $\delta$ なら $F_{y}=$ $F_{x} \cdot \tan \delta$ である。図一10 と同じく直線不連続線 $\Gamma^{*}$ を仮 定し $\triangle \mathrm{OAB}$ が剛性域であるとすると $u_{y} *$ の計算と同 様に, $\triangle \mathrm{OAB}$ 内で至るところ $u_{x} *=-\delta u^{*} \sin \left(\beta+\phi_{r}\right) /$ $\cos \phi_{r}$ となる。

式 (33)を用いると

$$
\begin{gathered}
\int_{S_{\boldsymbol{F}}}\left(\boldsymbol{F} \cdot \boldsymbol{v}^{*}\right) d S=\int_{\mathrm{OA}}\left(F_{x} u_{x}{ }^{*}+F_{y} u_{y}{ }^{*}\right) d y \\
\leqq r \int u_{y}{ }^{*} d V+c_{r} \int \delta u^{*} d \Gamma^{*} \\
\therefore \int_{\mathrm{OA}} F_{x}\left\{\frac{\sin \left(\beta+\phi_{r}\right)}{\cos \phi_{r}}+\tan \delta \frac{\cos \left(\beta+\phi_{r}\right)}{\cos \phi_{r}}\right\} d y \\
\geqq r \int \frac{\cos \left(\beta+\phi_{r}\right)}{\cos \phi_{r}} d V-\frac{c_{r} H}{\cos \beta} \\
\therefore \int_{\mathrm{OA}} F_{x} d y \geqslant \frac{r H^{2} \tan \beta \cos \left(\beta+\phi_{r}\right) \cos \delta}{2} \\
-c_{r} H \frac{\cos \delta \cos \phi_{r}}{\cos \beta \sin \left(\beta+\phi_{r}+\delta\right)} \cdots \cdots \cdots \cdots \mathrm{v}
\end{gathered}
$$

図-12
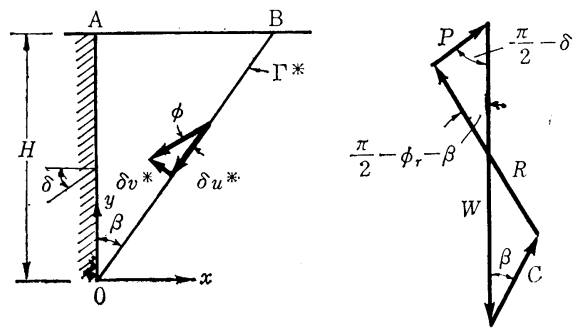

$\delta=0$ なら, $\beta=\pi / 4-\phi_{\boldsymbol{r}} / 2$ のとき右辺第 1 項は最大, 第 2 項は最小であって, その場合上式右辺は Rankine 土 压を表わす。また $\delta \neq 0$ であればv) の右辺は $\triangle \mathrm{OAB} の$ 重力 $W=\left(r H^{2} / 2\right) \tan \beta$ と $\Gamma^{*}$ 上の反力 $R$, 粘着抵抗 とつりあう力 $P$ (図一12 参照) の水平成分を表わす。し たがって右辺の最大值は Coulomb の主働土圧 (ただし 直線すべり面の仮定におけるもの）の水平成分であり， 正解水平力はそれより小さくなりえないことを示してい る。換言すると Coulomb の值よりも大きな土圧が可容

\begin{tabular}{c|c|c}
\multicolumn{2}{|c}{ 表一1 } & \multicolumn{2}{|c}{ 土圧係数の值 $(\delta=\phi)$} \\
\hline$\phi_{r}$ & 精密 解 & Coulomb 解 \\
\hline $10^{\circ}$ & 0.633 & 0.625 \\
$20^{\circ}$ & 0.409 & 0.404 \\
$30^{\circ}$ & 0.260 & 0.259 \\
$40^{\circ}$ & 0.162 & 0.162 \\
\hline
\end{tabular}

速度からえられれば， それは正解により近い ものとなる。しかし幸 に正解と Coulomb 值 との差はきわめて小さ いことは表一1に見ら

れるごとくである(山口，1959*)。

上記計算で $\triangle \mathrm{OAB}$ の変形が剛体的のもの, すなわち 壁面の変位が $-x$ 方向へ平行的移動をするとして可容速 度を考えたが，比較のため壁面が下端回りに回転する様 式を検討しよう。

図-13

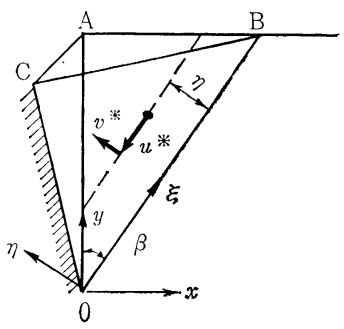

このため 図一13 に示 すごとく, $\triangle \mathrm{OAB}$ 内に $\mathrm{OB}$ に平行な連続的すべ り線ができているものと しクすべり線に沿う要素 の速度 $u^{*}$ が $\gamma_{\text {に比例 }}$ するものと考える。した がって, OBはもちろん $\triangle \mathrm{OAB}$ 内に $\boldsymbol{v}^{*}$ の不連 続線はない。 $u^{*}$ に対して $v^{*}=u^{*} \tan \phi_{r}$ が生ずるので

$$
\begin{gathered}
u^{*}=a \eta, v^{*}=a \eta \tan \phi_{r} \\
\therefore \bar{v}^{*}=\sqrt{u^{* 2}+v^{* 2}}=a \eta / \cos \phi_{r} \\
\therefore u_{x}^{*}=-\frac{a \eta \sin \left(\phi_{r}+\beta\right)}{\cos \phi_{r}}, \\
u_{y}{ }^{*}=-\frac{a \eta \cos \left(\phi_{r}+\beta\right)}{\cos \phi_{r}}
\end{gathered}
$$

これから $\mathrm{OA}$ 上で $y=\eta / \sin \beta$ なる点の $\bar{v}^{*}$ は $a y \sin \beta /$ $\cos \phi_{r}$ で, 図一13 の変形後の壁面 OC は下端回転型と なる。

$$
\text { 上の } u^{*}, v^{*} \text { から }
$$




$$
\begin{aligned}
& \dot{\varepsilon}_{\xi}^{*}=\frac{\partial u^{*}}{\partial \xi}=0, \quad \dot{\varepsilon}_{\eta}^{*}=\frac{\partial v^{*}}{\partial \eta}=a \tan \phi_{r}, \\
& 2 \dot{\tau}_{\xi \eta}{ }^{*}=\frac{\partial v^{*}}{\partial \xi}+\frac{\partial u^{*}}{\partial \eta}=a
\end{aligned}
$$

これから主ひずみ速度は

$$
\begin{aligned}
& \left.\begin{array}{l}
\dot{\varepsilon}_{1}^{*} \\
\dot{\varepsilon}_{2}{ }^{*}
\end{array}\right\}=\frac{\dot{\varepsilon}_{\xi}^{*}+\dot{\varepsilon}_{\eta}^{*}}{2} \pm \sqrt{\left(\frac{\dot{\varepsilon}_{\xi}^{*}-\dot{\varepsilon}_{\eta}^{*}}{2}\right)^{2}+\dot{\tau}_{\xi \eta}{ }^{* 2}} \\
& \therefore 2 \hat{\tau}_{\text {max }} *=\dot{\varepsilon}_{1} *-\dot{\varepsilon}_{2} *=2 \sqrt{\frac{a^{2} \tan ^{2} \phi_{r}}{4}+\frac{a^{2}}{4}} \\
& =\frac{a}{\cos \phi_{r}}
\end{aligned}
$$

以上によって式 (33) の各項は

$$
\begin{array}{r}
r \int u_{y} * d V=-\frac{r a \cos \left(\phi_{r}+\beta\right)}{\cos \phi_{r}} \int \eta d V \\
=-\frac{r a H^{3} \sin \beta \tan \beta \cos \left(\phi_{r}+\beta\right)}{6 \cos \phi_{r}} \\
2 c_{r} \cos \phi_{r} \int \dot{r}_{\max } * d V=a c_{r} \int d V=\frac{a c_{r} H^{2}}{2} \tan \beta \\
-\int_{S_{F}}\left(\boldsymbol{F} \cdot \boldsymbol{v}^{*}\right) d S=-\int_{\mathrm{OA}} F_{x}\left(u_{x}^{*}\right)_{\mathrm{OA}} d S \\
\left(\delta, F_{y}=0\right. \text { とす) } \\
=\frac{a \sin \left(\phi_{r}+\beta\right)}{\cos \phi_{r}} \int_{0}^{H} F_{x} y \sin \beta \cdot d y
\end{array}
$$

ここで $F_{x}$ の水圧的分布を仮定すると

$$
\begin{aligned}
&-\int_{S_{\boldsymbol{F}}}\left(\boldsymbol{F} \cdot \boldsymbol{v}^{*}\right) d S= \frac{P H a \sin \left(\phi_{r}+\beta\right) \sin \beta}{3 \cos \phi_{r}} \\
&\left(P=\int_{0}^{H} F_{x} d y\right)
\end{aligned}
$$

すなわち式 (33) より

$$
P>\frac{r H^{2}}{2} \frac{\tan \beta \cos \left(\phi_{r}+\beta\right)}{\sin \left(\phi_{r}+\beta\right)}-\frac{3 c_{r} H \cos \phi_{r}}{2 \cos \beta \sin \left(\beta+\phi_{r}\right)}
$$

右辺の最大值は $\beta=\pi / 4-\phi_{r}$ で生じ

$$
P>\frac{r}{2} H^{2} \tan ^{2}\left(\frac{\pi}{4}-\frac{\phi_{r}}{2}\right)-3 c_{r} H \tan \left(\frac{\pi}{4}-\frac{\phi_{r}}{2}\right)
$$

vi）をv）からえられる Rankine 土圧值とくらべると 第 1 項は同じであるが，第 2 項のため vi）の右辺はv) の右辺の最大值より小さくなる。すなわち粘着力のある ときは 図一13 のような下端回りの回転型の変位に対す る可容速度は起こり難いこととなる。これは粘性土の主 働状態での壁の変形が平行移動型の可能性が大きいこと を示し, 通常粘土の膨張的土圧と呼ばれる現象を説明し うるものといえよう。他方砂に限れば回転型, 移動型い ずれの可容速度に対しても同じ関係がえられる点は興味 のある点である。

以上の議論において $F_{x}$ の水圧分布の仮定の仕方に問 題がないわけではないが, 粘性土の膨張的変形が大きい 可能性をもつことの結論は妥当性があると考えられる。 それは直立のり面 $\left(F_{x} \equiv 0\right)$ の場合 vi) からは

$$
H \leqslant \frac{6 c_{r}}{r} \tan \left(\frac{\pi}{4}+\frac{\phi_{r}}{2}\right)
$$

がえられるからである。
土圧論における下界定理を論ずるには可容応力解を求 めねばならない。

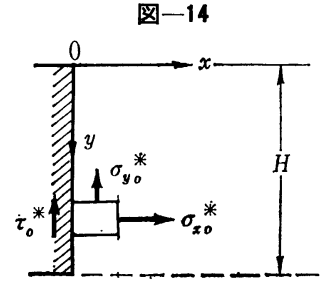

このような一つとして 図一14 の座標系に関して

$$
\begin{aligned}
& \sigma_{x} *=-K r y-A a^{2}\left(1-e^{-x / a H}\right) \\
& \tau^{*}=\frac{A a y}{H} e^{-x / a H} \\
& \sigma_{y} *=-r y+\frac{A}{2}\left(\frac{y}{H}\right)^{2} e^{-x / a H}
\end{aligned}
$$

を考える。vii) の応力系はつりあい式，境界条件

$$
\left.\begin{array}{l}
\frac{\partial \sigma_{x} *}{\partial x}+\frac{\partial \tau^{*}}{\partial y}=0, \frac{\partial \sigma_{y}{ }^{*}}{\partial y}+\frac{\partial \tau^{*}}{\partial x}=-r \\
y=0 ; \sigma_{y}{ }^{*}=0, \tau^{*}=0
\end{array}\right\}
$$

を満たしている。

末知定数 $A, a, K$ を決めるためまず $x=0$ で

$$
\begin{aligned}
& \sigma_{x_{0}} *=-K r y, \tau_{0} *=A a y / H, \\
& \sigma_{y 0} *=-r y+A y^{2} / \tau H^{2}
\end{aligned}
$$

であるが，壁面条件

$$
\tau_{0}^{*}=-\sigma_{x_{0}} * \cdot \mu(\mu=\tan \delta)
$$

を考え $\left(-\sigma_{x_{0}} *\right.$ は圧応力に注意 $)$

$$
A a=K r H \mu
$$

$$
\text { よってふたたび }
$$

$$
\begin{aligned}
& \sigma_{x_{0}} *=-K r y, \tau_{0}{ }^{*}=K r \mu y, \\
& \sigma_{y_{0}}{ }^{*}=-r y+\frac{K \gamma H \mu}{2 a}\left(\frac{y}{H}\right)^{2}
\end{aligned}
$$

をうる。

$a$ の值は $x=\infty$ で降伏が生じない条件に適するもの でなければならない。ただし $a>0$ 。

vii）より $x \rightarrow \infty$ では $A a=K r H \mu$ に注意し

$$
\begin{aligned}
& \sigma_{y \infty}{ }^{*}=-r y, \tau_{\infty} *=0, \\
& \sigma_{x \infty} *=-K r y-K r H \mu a
\end{aligned}
$$

したがって $\sigma_{x \infty} *$ - $\sigma_{y \infty} *$ なる最大せん断応力に比例す る項は $y=H て ゙$ 最も大きく，そこで降伏しないためには

$$
\sigma_{x \infty} *-\sigma_{y \infty} * \leqslant-\left(\sigma_{x \infty} *+\sigma_{y \infty} *\right) \sin \phi_{r}(y=H)
$$

ただし $c_{r}=0$ とす。

$$
\therefore a \geqq \frac{(1-K)-(1+K) \sin \phi_{r}}{K \mu\left(1+\sin \phi_{r}\right)}
$$

viii）だけからは $a$ がまだ決まらぬが， $a$ を仮定して 求めた $K$ が viii）を満足するようになればよい。

$K$ を定めるには降伏が壁面 $(x=0)$ で生ずる関係を用 いる。 $x=0$ でも $y=H$ でせん断応力の絶対最大值が生 ずる。すなわち

$$
\sigma_{x 0} *-\sigma_{y_{0}} *=r y(1-K)-\frac{K r H \mu}{2 a}\left(\frac{y}{H}\right)^{2}
$$




$$
\frac{d}{d y}\left(\sigma_{x 0} *-\sigma_{y 0} *\right)=r\left[1-K\left(1+\frac{\mu y}{a H}\right)\right]
$$

よって,

$$
K\left(1+\frac{\mu}{a}\right) \leqq 1
$$

なら $\left(\sigma_{x 0} *-\sigma_{y_{0}} *\right)$ は $y$ に対し単稠増大で $y=H$ で最大 となる。 $\tau_{0}^{*}$ も $y=H$ で最大となり主応力差は $y=H$ で 最大となる。ix）は $a$ の満たすべきもう一つの条件で ある。

$x=0, y=H$ で降伏が生ずるためには

$$
\begin{gathered}
\left(\sigma_{x_{0}} *-\sigma_{y_{0}} *\right)^{2}+4 \tau_{0}{ }^{2}=\left(\sigma_{x_{0}} *+\sigma_{y_{0}} *\right)^{2} \sin ^{2} \phi_{r} \\
\therefore\left[(1-K)-\frac{K \mu}{2} a\right]^{2}+4(K \mu)^{2} \\
=\left[(1+K)-\frac{K}{2} \frac{K}{a}\right]^{2} \sin ^{2} \phi_{r} \ldots \ldots \ldots \ldots
\end{gathered}
$$

が $K$ を与える式となる。

$\phi_{r}=30^{\circ}, \mu=0.2$ の場合

$$
\begin{aligned}
& a=0.5 \text { なら } K=0.322 \\
& a=0.4 \text { なら } K=0.309
\end{aligned}
$$

となる。これに対しいずれも viii), ix）の不等式を満足 するが $a=0.4$ のとき viii) の右辺は 0.392 であり $a=$ 0.4 でほぼ $K$ は最小となる。

ところで下界定理によると式 (22) で，主働時に $U_{\boldsymbol{y}}$ $=0, U_{x}=$ 一定（負值であることに注意）としてよいか Б

$$
F_{x} *>F_{s}
$$

すなわち $\sigma_{x 0} *$ の最小値として正解応力 (壁面平行移動 時)の近似解がえられ, 上記例では土圧係数として 0.309 がえられた。Coulomb 公式による $K$ の值は 0.305 であ り, Janbu の分割法式による場合 0.306 である (Janbu 1957)。

上記のことから vii) が主働状態の生ずる時点での連続 的応力解として十分な近似性をもつものであることが推 定できる。

（3）支持力論で上, 下界定理を考察するため地表面 上の帯基礎を例にとる。任意の点 $L$ を極とし基礎の一 端 $O$ を通る対数螺線 $r=r_{0} \exp \left(\theta \tan \phi_{r}\right)$ は(1) で説明 したように，その曲線を不連続線とし，領域 OCB を剛 体域とする可容速度場を形成する。いま $L$ の回りに $\delta \dot{\omega}$ なる角速度を与えると要素変位速度 $\rho \delta \dot{\omega}$ は $u_{y}{ }^{*}$ なる速 度成分をもち， $\Gamma^{*}$ 上でも $\delta u^{*}=r \delta \dot{\omega} \cos \phi_{r}$ が生ずる。

\section{図 15}

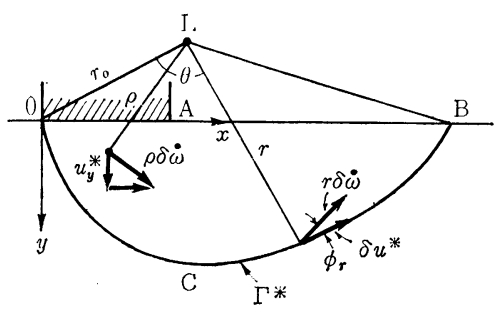

境界は $S_{V}=0$ で $\mathrm{OA}$ 上の摩擦がなく $F_{y}$ だけを考える と上界定理 (33) は

$$
\begin{aligned}
\int\left(\boldsymbol{F} \cdot \boldsymbol{v}^{*}\right) d S= & \int_{\mathrm{OA}}\left(F_{y} \cdot u_{y}{ }^{*}\right) d x \leqq \\
& -r \int u_{y}{ }^{*} d V+c_{r} \int \delta u^{*} d \Gamma^{*}
\end{aligned}
$$

となる。ここで $-r$ と負号がついたのは, 式 (33) を導 く場合と $y$ 軸のとり方が逆であるからである。Lを通る 鉛直線の左では $u_{y}{ }^{*}>0$, 右では $u_{y}{ }^{*}<0$ であるので上 式は,

$$
\begin{aligned}
\int_{\mathrm{OA}}\left(F_{y} \cdot u_{y} *\right) d x & +\gamma \int_{l_{e}}\left|u_{y} *\right| d V \\
& <\gamma \int_{r_{i}}\left|u_{y} *\right| d V+c_{r} \int \delta u^{*} d \Gamma^{*}
\end{aligned}
$$

ただし $l_{e}$ は左側, $r_{i}$ は右側

と書くことができiv）を導いたのと同じく，左辺は $M_{D}$, 右辺は $M_{R}$ を表わす。よってこの場合も $M_{D} \leqq M_{R}$ が いえる。明らかに正解表面力はこのような可容速度に適 合した表面力を越えることはなく，できるだけ $M_{R} / M_{D}$ の小さくなるようにせねばならない。これは安定解析な どで慣用される安全率最小法則を証明したことにほかな らない。

下界定理 (22) によると基礎が一様に $U$ で沈下すると き可容表面力を $F_{y} *$ とし $, F_{y}, F_{y}{ }^{*}, U$ がいずれも $y$ の 正方向に向うことから

$$
Q=\int_{\mathrm{OA}} F_{y} d x \geqq Q^{*}=\int_{\mathrm{OA}} F_{y} * d x
$$

である。

$F_{y}{ }^{*}$ としては弾性応力解が採用できる。このような試 みは多くの人によってなされており (Fröhlich, Maslow, Jaroporskij, 星埜など) ここに再言する要はないであろ う。しかしながら弾性解を根入れのある，すなわち境界 が厳密には半無限でないものについて, そのまま適用さ れていること,さらに自重による水平圧力と鉛直圧力を 等しいと仮定していることなど検討を要する面があるこ とは指摘されねばならない。

\section{7. 結}

\section{論}

本論文で土のような自重と摩擦強度を無視しえない材 料を, 剛塑性体すなわち Hvorslev 規準によって降伏す るものと仮定した場合の可容応力, 可容速度に関するリ ミットデザインの定理の形式を明らかにし，かつ応力や 速度に不連続性がある場合の解析表示を行なった。その 結果

（1）下界定理に関しては金属塑性論と全く同じ形の ものが成り立つことが知られた。

（2）上界定理は自重や不連続線上の可容速度を含む ところの一般性ある形式が導き出された。これは Drucker, Prager の崩壊定理として知られてい る命題をも包括し，より応用性の大きいものであ 
る。

（3）ここにえられた_上, 下界定理を用いて, 変形す る塑性場内の応力解の一意性が証明できた。

（4）のり面安定の例として, 直立のり面の自立高を 調べ, 上界定理の結果が Drucker の結論と一致 することを示し，曲線不連続線での上界定理が滑 動, 抵抗モーメントの大小の比較に帰着するこ と,すなわち最小安全率の法則を意味することを 明らかにした。

（5）支持力についても上界定理の忘用は（4）と全く 同じことになることがわかった。

（6）土圧論に応用し, 下界定理に応用できる近似性 のよい連続的応力解を与えた, これは地表および 壁面でのすべての条件と無限遠の物理的特性を満 たすものである。また上界定理を不連続な可容速 度と, 連続的な可容速度の二つの場合に比較し, 砂 質土では両者の与える土圧の変分法則は全く一致 するが, 粘性土では連続的な可容速度は起こり難 いものであることが推論された。その結果砂と粘 土で主働状体の壁面の変位状況が, 前者は回転型 が可能であるに反し, 後者では平行移動型が起こ りやすいことが結論された。なお, 本論文の解析 は Coulomb, Rankine 土圧の現代的な解釈を示 したことになる。

なお今後, 間げき水圧のある場合の極限定理, 基礎の下 界法則に適用しうるより近似性の高い可容応力解などに ついて研究を進めて行くつもりである。

\section{参 考 文 献}

1) Bishop, A.W. (1966): The strength of soils as engineering materials. Geotechnique 2

2) Drucker, D.C. \& W. Prager (1952) : Extended limit design theorems for continuous media. Quart. Appl. Math. 9

3) Drucker, D.C. \& W. Prager (1952*) : Soil mechanics and plastic analsis or limit design. Quart. Appl. Math. 10

4) Drucker, D.C., H.J. Greenberg \& W. Prager (1951) : The safety fectors of an elastic-plastic body in plane strain. J. Appl. Mech. 18

5) Hill, R. (1948): A variational principle of maximum plastic work in classical plasticity. Quart. J. Mech. Appl. Math. 1

6) Hill, R. (1951) : On the state of stress in a plastic rigid body at the yielding point. Phil. Mag. 42

7) Hill, R. (1956): On the problem of uniqueness in the theory of a rigid plastic solid, I. J. Mech. Phys. Solids 4

8) Janbu, N. (1957) : Earth pressure and bearing capacity calculation by generalized procedure of slices Proc. 4 th L.C.S.M. II

9) Shield, R.T. (1954) : Stress and velocity fields in soil mechanics. J. Math. Phy. 33

10) Taylor, D.W. (1937) : Stability of earth slopes. J. Boston Soc. Civil Engrs. 24

11）山口柏樹（1959）：土の塑性流動における速度場の理論, 土木学会論文集 63

12) 山口柏樹 (1959)：Kötter の方程式の理論上貿力学への 適用, 土木学会論文集 65

13）山口柏樹 (1966)：正規圧密粘土の岡塑性理詷, 土質工学 研究発表会 1

14）山口柏樹（1967）：土の塑性力学に抢ける伈力と速度の不 連続性について, Soil. Found. 几発表の予定

(1967.1.19. 受付) 